\title{
Influence of Career Management on Employee retention in Mobile Telecommunication Companies in Kenya; A Case of Safaricom Public Limited Company (PLC)
}

\author{
Mr. Anjia Zeddy Musambai ${ }^{\# *}$ and Dr. Clive Malietso Mukanzi^ \\ \#MSc Scholar, College of Human Resource Development, Jomo Kenyatta University of Agriculture \& Technology, Kenya \\ ^Lecturer, College of Human Resource Development, Jomo Kenyatta University of Agriculture \& Technology, Kenya \\ Received 10 Aug 2018, Accepted 12 Oct 2018, Available online 15 Oct 2018, Vol.6 (Sept/Oct 2018 issue)
}

\begin{abstract}
This study sought to investigate the influence of Career Management on employee retention in Mobile Telecommunication companies in Kenya. It adopted a descriptive research design. Primary data was collected from a sample of 274 employees of Safaricom Plc Hypothesized relationships were tested using regression analysis. The results indicate that career management positively and significantly influence employee retention. Therefore it is recommended that mobile telecommunication companies have to build and nurture strong career management practices as key result areas if they are to retain key talent.
\end{abstract}

Keywords: Talent management, Talent management practices, career management, employee retention, career growth, career development, career pathing

\section{Introduction}

In the modern day competition, talent has become a precious resource, sought and fought over by competitors in a global 'war for talent' (Cheese, Thomas \& Craig, 2008). For most organizations, filling key positions is a very important means of developing and ensuring sustainability of the competitive edge (Thunnissen, Bosselie \& Fruytier, 2013). Retaining talented employees is the priority of many organizations and it is the key differentiator of human capital management (Mohammed, 2015).

Organizations have increasingly recruited talent away from their competitors, creating retention tension (Capelli, 2015). The demand for competent employees is high especially for key decision-making workforce; therefore organizations are exposed to a continuous competitive fight for the best and talented employees (Kibui, 2015). Research indicates that satisfied employees due to good career management practices tend to be committed to an organization (Cooper-Hakim \& Viswesvaran, 2005), and employees who are satisfied and committed are more likely to stay with the organization (Ngirande \& Muzana, 2014).

Talent management practices consist of a wide range of activities which different organizations adopt such as

*Correspondin author's ORCID ID: 0000-0002-9899-4976 DOI: https://doi.org/10.14741/ijmcr/v.6.5.16 compensation management, talent attraction, talent development, talent retention, performance management, competency management, skill development, training and development, learning and development, leadership development, succession planning, career management, workforce planning and many others (Bersin \& Deloitte, 2010; Armstrong, 2010). These are methods employed by organizations to assist in the retention of their employees (Human Capital Institute, 2008). The practices adopted generally differ from industry to industry in many cases and certain practices are more suitable for certain industries over others (Ochieng, 2016).

The telecommunication industry is regulated by the Communication Authority (CA). The mobile telecommunication industry has three operational GSM Mobile Service Providers (MSPs); Safaricom, Airtel, and Orange Kenya, and one mobile virtual network providerEquitel (CA, 2015). Safaricom is the leading MSP with 76.7 percent market share; Airtel has a market share of 20 percent, Orange Kenya having a market share of 3 percent and Equitel 0.3 percent market share (KNBS, 2015; CA, 2015).

The telecom sector in Kenya is well developed having two major players Safaricom and Telkom Kenya. Safaricom is the clear market leader in the mobile services segment while Telkom Kenya is the major player in the fixed line telecom segment (GOK, 2014). Owolabi 
and Makinde (2014), observed that the issue of employee satisfaction in leading mobile subscribers in Kenya especially Airtel Kenya, may be affected by the level at which the company recruits its employees and the way it manages its employee retention processes.

Employee retention issues are emerging as the most critical workforce management challenges of the immediate future (Rono \& Kiptum, 2017). Once an organization has captured skilled employees, the return on investment requires closing the back door to prevent them from walking out (Kubaison, Mukangu \& Rutiria, 2015). Employees are more likely to remain with the organization only if they believe that the organization shows more interest and concern for them, if they know what is expected of them, if they are given a role that fits their capabilities, and if they receive regular positive feedback and recognition (Samuel \& Chipunza, 2013).

Employee retention and talent management practices of successful companies are fundamental element to maintain their leadership and development in the marketplace (Kurbetta \& Mehta, 2014). An organization's talent management strategy should contribute to employee engagement, effective recruitment and retention of employees. This will create positive employer brand, employees will want to stay with the organization, which will minimize turnover (Julia, Hughes \& Rog, 2008).

Retention of key talent; that employee who is a strong performer, have high potential or are in critical jobs is even more important during economic recoveries when organizations compete aggressively for market share and talent (Kigo, 2016). Key talent disproportionally contributes to current organization performance and to future performance since key employees often become organization leaders. Losing key talent costs considerably more since these employees' impact and contribution are greater than that of typical employees (McMullen \& Mark, 2012).

Retention of talent employees is critical to preserving skills of such employees (Chikumbi, 2011). By so doing, a business can avoid losing customers so that they maintain high quality products that are marked by high sales. Employees who work together for a long time will enjoy a healthy working atmosphere, good relations with managers, effective succession planning and deeply embedded organisational knowledge and learning. Failing to retain key employees especially new graduates is costly for any business. Mendez and Stander (2011) further emphasises that a company needs to invest in employee retention in order to be successful. For example, a good compensation package is important in retaining employees, offering an attractive, competitive benefits package with components such as life insurance, disability insurance and flexible hours motivates employees to commit themselves to an organization (Ahmed, 2016).

It is important and difficult to retain talented employees under high unemployment levels. It is important to retain them because of high training and recruitment costs so organizations use rewards to retain employees (Simon North, 2011). Furthermore, Ratna and Chawla (2012) argued that retention is more important than hiring, even though hiring knowledgeable people is essential for an employer. Employee retention also indicates taking the appropriate measures to encourage people to stay in the organization as long as they can. Ratna and Chawla (2012) state that "The process of employee retention will benefit an organization as the cost of employee turnover adds hundreds of thousands of money to a company's expense." It also means that if a company has a higher employee retention rate, it will motivate potential employees to join the company.

McNally (2011) found some ways of retaining valued employees, such as designing a compensation programme to reward valued employees, career opportunity, development and growth paths they need to develop, encouraging work-life balance and good communication. McNally stated that "Give your most valued employees the best opportunities, coaching and rewards, knowing that the key to your company's success is their retention."

Employees must be able to see a clear career path in the organization, only then they will stay for long (Bagga, 2013). Providing great career development opportunities makes the employees to stay in the company for long and at the same time enhances their loyalty to the firm. Also creating a positive social work environment and adding content to the jobs and tasks to be done by the employees enhances employee satisfaction and commitment (Meganck, 2007).

In an exploratory study to identify ways to retain talent conducted in professional organizations Govaerts et. al., (2010) collected a sample of 972 employees and concluded, to retain employees it is important to pay attention to learning of employees. Learning and development of employees plays a key role in talent management strategy. In order to retain people, organizations should allow people to learn more and do more in what they are good at. This kind of talent management practices leads to satisfied employees, which lead to retention. The study further identifies a positive relationship in intention to stay with the company and age of the employees. Using different talent management practices, the company is able to retain employee for a longer period, the less will be the intention of employee to leave job (Mehta, 2014).

In order to keep attrition low, managers must provide sufficient training to employees to attain the necessary Knowledge Skills and Abilities (KSA) to perform better, so that older employees in the organization are at the same expertise level as compared to their younger counterparts (Taplin, Winston \& Winterton, 2007). Well-trained workers stay loyal to their employees (Leidner, 2013). Access to training, adjusting training practices as per older employees requirements and an age-awareness training program is required for better older employee retention (Marjorie, Stassen \& Templer, 2004). Lastly, it is 
important to retain employees otherwise; it leads to wastage of training costs. Employee retention is a technique adopted by businesses to maintain an effective workforce and at the same time meet operational requirements (Kurbetta \& Mehta, 2014).

\section{Statement of the problem}

Currently, organizations are facing the challenge of retaining their skilled talent (Schuler, 2011; Scullion, 2010; Tarique \& Schuler, 2010). According to the Kenya National Bureau of Statistics (2012), at least 20 per cent of employees leave their organisation, this severe drain of talents from organizations has not spared mobile telecommunication sector. The high rate of employee turnover in these organizations can be attributed to the fact that many managers have dismissed talent management as a non-issue and have not put in place strategies to retain talent in their organization (Rono \& Kiptum, 2017). Usually, the lack of staff retention in these organizations has had adverse effects on service delivery (Ng'ethe, Iravo \& Namusonge, 2012). According to the Annual Report, Safaricom has experienced a staff turnover of approximately 6.0 per cent (Safaricom Annual Report, 2016), 20 percent Airtel (Nding'ori, 2015; Odembo, 2013) and 35 percent in Telkom Kenya (Muteti, 2013).

Several studies have been done on talent management (Ochieng, 2016; Ndung'u \& Omondi, 2015; Silvia, 2014; Omondi, 2013; Wambui, 2012), many of whom have studied about how talent management affects competitive advantage (Hejase et al., 2016; Chepkwony, 2012) however, there is limited research that has been done on how talent management influence employee retention in the mobile telecommunication industry in Kenya. Nonetheless, despite a significant growth in talent management literature, most studies were carried out in other sectors such as banks (Karuri, 2015; Ndung'u \& Omondi, 2015; Kibui, Gachunga \& Namusonge, 2014; Silvia, 2013), commercial state corporations (Mwajuma, 2015; Njeri, 2014; Kagwiria, 2013; Wambui, 2012), training institutions (Katitia, 2014), in supply chain (Ochieng, 2016) and healthcare industry (Mukweyi, 2016; Karemu, Kachori, Josee \& Okibo, 2014). Therefore, there are significant gaps between talent management and employee retention scholarship in mobile telecommunication industry in Kenya, which the current study sought to address.

\section{Research objective and Hypothesis}

To investigate the influence of Career Management on Employee Retention in the Mobile Telecommunication Companies in Kenya; a case of Safaricom Plc

i. $\quad \mathrm{H}_{01}$ Career management has no significant influence on employee retention in Mobile Telecommunication Companies; a case of Safaricom PLC

\section{Methodology}

The study used the lenses of the pragmatism philosophy to adopt a descriptive study research design. Descriptive studies are data collection methods and techniques which are based on an in-depth rather than in breadth analysis of a research unit in detail. The design was done by administering of a questionnaire that was written to a group of respondents with the responses to form the data for the study. Descriptive studies fit quite well with the investigation of the outcomes of talent management practices. Other scholars (Matata, 2017; Muriuki, 2017; Wanjiku, 2017; Knott, 2016; Mukweyi, 2016; Ochieng, 2016; Abok, 2015; Kibui, 2015; Mugo, Minja \& Njanja, 2015; Kimani \& Waithaka, 2013; Njoroge, 2012;) who have researched on related topics used a similar research design in their studies. The study targeted a population of 4192 employees of Safaricom (Safaricom Annual Report, 2016). These employees mainly categorized into three levels of operation; senior management, Supervisory and General staff. All the Top management was sampled to conform to the Central Limit Theorem (CLT) because they were thirty and below, as a result, the characteristic of this data was divided into two strata (i.e. supervisors and those in the lower cadre). Therefore, stratified sampling technique was used. Stratified sampling is a process in which certain subgroups or strata are selected for the sample in the same proportion, as they exist in the population (Kothari \& Garg, 2014; Fraenkel \& Wallen, 2006). Therefore, the sample size for each stratum was obtained by proportionate allocation using Krejcie and Morgan (1970) formulae.

The study gathered primary information by use of questionnaires which consisted of two parts and six sections. Part I obtained the demographic information of respondents such age, gender, education level and length of service. On the other hand, part II was divided into six sections, A-F which sought to obtain responses to the likert scale items on career management together with employee retention.

A pilot study was conducted to establish both reliability and validity of the research instruments. To obtain the reliability coefficient, the questionnaires distributed for a pilot study were received and coded. They were entered in SPSS program and the Cronbach's test approach used to test for reliability of the questionnaire items. The Cronbach's Alpha coefficient was obtained for all variables; career management and employee retention. They all gave a Cronbach's alpha coefficient SPSS output of more than 0.7. Thus, Cronbach's alpha scanning is one of the ways used to assess for internal consistency of each variable was used in the study (Cooper \& Schilder, 2011; Fraenkel \& Wallen, 2006; Serakan, 2003). Kothari and Garg (2014) posited that a Cronbach's coefficient greater than 0.7 is acceptable and usually expressed as $0 \geq \alpha \leq 1$.

Internal validity was ensured by selecting and adapting questionnaire items from previous relevant 
researches (Ochieng, 2016; Mbugua, Waiganjo \& Njeru, 2015; Tunje, 2014; Xue, 2014; Mukweyi, 2014; Kibui, 2013). On the other hand, construct validity was established by referring the research instrument to professional judgment for checking as to whether it measures the claimed measure. Therefore, a questionnaire can be considered as valid if the content and format test really measures what it should measure (Fraenkel \& Wallen, 2006).

This study used both inferential and descriptive statistics to summarize the demographic profiles of respondents and the results presented in charts and tables. Percentages were used to analyse and present the various responses to statements that helped the study to measure the specific variables. Correlations and regressions were inferentially used to test for the various objectives. Linear and multiple regressions were also used to establish the direction and strength of the relationship between talent management practices and employee retention.

According to Tabachnick and Fidel, (2001) correlation tends to measure the direction and magnitude of the relationship between two variables.
When correlation analysis was completed, a regression analysis was conducted.

One multiple regression model was used to investigate the influence of talent management practices on employee retention in this study. The regression model that was used in this study is as shown in the equation;

$Y=\alpha+X_{1} \beta_{1}+\mu$ Where $Y$ is Employee Retention; $X_{1}$ is career management; $\beta 1-\beta_{5}$ are regression coefficients; $\mu$ is the error term; $\alpha$ is a constant or the $y$-intercept

\section{Results of the study}

To test the amount of variation of the independent variable (career management) on the dependent variable (employee retention), a regression analysis was carried out. In relation to the results of a correlation, it was found that career management has a positive and significant influence on employee retention $(r=0.760 * *, p<0.001)$.

Table 1: Career Management on Employee retention

\begin{tabular}{|c|c|c|c|c|c|c|c|}
\hline \multicolumn{9}{|c|}{ Model Summary } \\
\hline \multirow{2}{*}{ Model } & \multirow{2}{*}{$\mathrm{R}$} & \multirow{2}{*}{ R Square } & \multirow{2}{*}{ Adjusted R Square } & $\begin{array}{c}\text { Std. Error of the } \\
\text { Estimate }\end{array}$ & \multicolumn{3}{|c|}{ Change Statistics } \\
\cline { 5 - 8 } & & & & R Square Change & F Change & Sig. F Change \\
\hline 1 & $.760^{\mathrm{a}}$ & .578 & .576 & .54380 & .578 & 372.596 & .000 \\
\hline \multicolumn{8}{|c|}{ a. Predictors: (Constant), Career Management } \\
\hline
\end{tabular}

Table 2: Regression Coefficients for career management

\begin{tabular}{|c|c|c|c|c|c|c|}
\hline \multicolumn{7}{|c|}{ Coefficients $^{\mathrm{a}}$} \\
\hline & \multirow[t]{2}{*}{ Model } & \multicolumn{2}{|c|}{ Unstandardized Coefficients } & \multirow{2}{*}{$\frac{\text { Standardized Coefficients }}{\text { Beta }}$} & \multirow[t]{2}{*}{$\mathrm{t}$} & \multirow[t]{2}{*}{ Sig. } \\
\hline & & $B$ & Std. Error & & & \\
\hline \multirow{2}{*}{1} & (Constant) & .767 & .174 & & 4.405 & .000 \\
\hline & Career Management & .831 & .043 & .760 & 19.303 & .000 \\
\hline \multicolumn{7}{|c|}{ a. Dependent Variable: Employee Retention } \\
\hline
\end{tabular}

The results in table 1 shows the measure of variation of the predicted variable (employee retention) as explained by the predictor variable (career management). The regression analysis output in yielded a coefficient $R$ value of 0.760 and $R^{2}$ of 0.578 which implies that 57.8 per cent of the corresponding variance in employee retention can be predicted by career management. The rest of the percentage could be explained by other variables not included in this model. The $\mathrm{F}$ test statistic gave a value of $\mathrm{F}=372.596, \mathrm{P}<0.01$, which was large enough to support the goodness of fit of the model in explaining the variance in the dependent variable (employee retention) by the independent variable (career management). This finding validates the fact that career management is a useful predictor of employee retention. This means that employees who experience higher levels of career management will also have higher levels of employee retention.
The coefficients of the fitted model using the "unstandardized coefficients" were given in the table 2;

Equally, the unstandardized regression coefficients $\beta$ value of the computed (composite index) scores of career management was 0.831 with a t-test of 19.303 and at a significance level of $p<0.01$. This implied that for every 1 per cent increase in career management there was a predicted increase in the percentage of employee retention of zero. Having achieved the objective, the study rejected the null hypothesis that;

$\mathrm{H}_{01}$ : Career Management has no significant influence on employee retention in the Mobile Telecommunication companies in Kenya; a case of Safaricom Plc

Employee Retention (predicted) $=-1.807+0.459 *$ Career management 
In the establishment of how useful the predictor variables could be, Cohen and Cohen (1983) recommended that the $t$ - values should be less than -1.96 or greater than +1.96 at 95 per cent confidence level. Therefore, the results obtained presented the $t$-values of career management $(\mathrm{t}=8.559)$. This showed that the $t$-value of career management was within the range and hence, the variable was found to be a significant predictor of employee retention in the multiple regression since it had $p$ value of less than 0.01 . However, on the overall, this shows that when a given set of employees' experiences are increased in terms of the provision of talent management practices, then there would be a subsequent increase in employee retention by the given $t$ - values respectively. Thus, having achieved the set objective, the study rejected the null hypothesis that:

$\mathrm{H}_{0}$ : Talent Management practices have no significant influence on employee retention in Mobile Telecommunications companies in Kenya; a case of Safaricom Plc.

\section{Discussion of findings}

The findings indicated that the influence of career management on employee retention is strongly positive and significant $(r=0.760 * *, p<0.01)$. These findings are consistent with those of Nazir et al. (2016) who posited that both career development and pathing are significantly related to employee retention. The findings also corroborate those by Foday (2014) who found out that, the independent variables exhibit values that are above 5 per cent. Generally, this means that there is a strong positive correlation between the career management practices, and employee retention. These findings are also in line with those of Kamau (2017) who carried out a study on the influence of career management practices on employee retention, the study concludes that career management practices such as training and development, mentoring and coaching had a positive and significant influence on employee retention. Wane (2016) also carried a study on the perceived relationship between career management practices and employee retention. The results reveal that the correlation between career development practices and employee retention exhibit a strong positive correlation of $\mathrm{R}=0.830$ which means that there exists a strong positive relationship between career development practices and employee retention. These findings also corroborate the findings of other scholars (Chelimo, 2014; Ondimu, 2013; Maina, 2011). According to Maina (2011) and Wambui (2013) career management is positively and significantly correlated to staff retention. The findings are also in tandem with those of Sitati, Were and Gichuhi (2016) who investigated the relationship between career development practices and employee retention. The study reveals a positive and significant relationship between career management practices and employee retention.

\section{Conclusions}

From the results in the table above it is evident that Safaricom Plc has elaborate career management strategies that are clearly defined and suited to employees' needs. These include career development plan, career development policy, career mentorship programs and internship programs that are meant to allow the employees to advance their careers in the organization as well as enhancing professional growth. Therefore, a majority of respondents were in favour of the fact that professional advancement is an important component of their enhanced performance. Hence continued stay at the organization.

\section{Recommendations}

The study reported that career management dimensions of career development policy, career pathing and career growth programs adopted by mobile telecommunication companies in Kenya, highly influenced the companies' retention, loyalty as well as improving companies' image. It is therefore recommended that the management of mobile telecommunication companies in Kenya should foster on nurturing and building strong career management practices that would make both management team and employees have identity with the organization and work to achieve a common goal; retention as well as competitive advantage.

\section{Acknowledgement}

The authors acknowledge employees of Safaricom Plc for their time to respond to the questionnaires.

\section{References}

[1]. Armstrong, M. (2009). Armstrong's Handbook of Human Resources Management. Kogan Page, UK.

[2]. Bersin and Associates (2013). Global Forces Drives New Models for Talent. Bersin by Deloitte. Retrieved from http://www.ihrc.ch/wpcontent/uploads/2013/03/predictions-2013-final-1.pdf.

[3]. Business Management Review, (2013). Challenges Facing Management in Kenya. Retrieved May 2017 from http://businessreviewkenya.com/challengesfacingmanagement- in-kenya/.

[4]. Chemaiyo, A. K., (2016). Talent Management and Its importance in Today's Organization in Kenya Perspective; A critical review; International Journal of Advances in Management and Economics

[5]. Chelimo, L (2014). Employee Perceptions of the Effectiveness of Career Management Practices at Kenya Airports Authority; University of Nairobi

[6]. Chikumbi, C.L. (2011). An Investigation of Talent Management and Staff Retention at the Bank of Zambia. Masters in Business Administration. Nelson Mandela Metropolitan University Business School.

[7]. Chiboiwa, W. M \& Samuel, M. O., \& Chipunza, C. (2010). An examination of employee retention strategy in a private 
organisation in Zimbabwe. African Journal of Business Management. 4. 2103-2109.

[8]. Cooper-Hakim, A., \& Viswesvaran, C. (2005). The construct of work commitment: testing an integrative framework. Psychological Bulletin, 131, 241-259.

[9]. Deloitte (2010). Talent Edge 2020: Blueprints for the New Normal. Deloitte Development LLC

[10].Deloitte (2012). Staff Retention Requires Alignment of Needs and Strategy: HRM Reward

[11]. Deloitte (2014). Global Human Capital Trends 2014: Engaging the 21st-century Workforce. Retrieved March 12, 2017 from http://www.deloitte.com

[12]. Fraenkel R. \& Wallen, N.E. (2006). How to Design and Evaluate Research in Education. McGraw-Hill Publishing Company, New York.\#

[13]. Julia C. H., and Evelin R., (2008), A strategy for improving employee recruitment, retention and engagement within hospitality Organization, International Journal of Contemporary Hospitality Management, 20 (7) 743-757

[14]. Kamau, G.K., Kachori, D., Josee, M. V. \& Okibo, W. (2014). Critical Analysis of Talent Management Strategies on Medical Employees Retention in Public Hospitals in Kenya; A case of Kenyatta National Hospital; European Journal of Business and Management 6 (23)

[15]. Karemu, G. K., Kachorii , D., \& Josee, V. M. (2015). Critical Analysis of Talent Management on Medical Staff Retention: A case of Kenyatta National Hospital in Kenya. European Journal of Business and Management, 6 (23).

[16]. Kataike, C. (2013). The Relationship between Talent Management and Employee Retention in the Banking Industry, Unpublished, University of Nairobi

[17]. Katitia, P. K., (2014). Motivational Factors Influencing Employee Retention in Multi Purposes Training Institutions: A Survey of Selected institutions in Kenya; Unpublished Project. Kenya: University of Nairobi.

[18]. Krejcie, R. \& Morgan, D. (1970). Determining the Sample Size for Research Activities. Educational Psychology Measures

[19]. Kwenin, D.O. (2013). Relationship Between Work Environment, Career Development Opportunities \& Employee Retention in Vodafone Ghana limited. Global Journal of Human Resource Management, 1(4), 1-9

[20]. Lyria, R., Namusonge, G., \&Karanja, K. (2014). Effect of Career Management to the
[21]. Organizational Performance in Companies Listed in Nairob Security Exchange in Kenya. International Journal of Science and Research, 3(7), 1916-1921.

[22]. Maina, A, R (2011). Factors Affecting Career Management among Non-Academic Staff in Public Universities in Kenya: A Case Study of Jomo Kenyatta University of Agriculture \& Technology; Master's Thesis; Jomo Kenyatta University of Agriculture \& Technology

[23]. Mendez \& Stander (2011). Positive Organization. 'The role of leader Behaviour in work engagement and Retention', South African Journal of Industrial Psychology, (37)1.

[24].Ndung'u D. K. (2015). Relationship between Talent Management Practices and Employee Turover; A case study of the Co-Operative bank of Kenya; Strategic Journal of Business \& change Management 2115

[25]. Ng'ethe, J. M., Iravo M. E., Namusonge, G. S., (2012) Determinants of Academic Staff Retention in Public Universities in Kenya: Empirical Review; International Journal of Humanities and Social Science, 2(1) 205-212

[26].Rono, J. E., Kiptum, K. G., (2017). Factors Affecting Employee Retention at University of Eldoret, Kenya; Journal of Business \& Management 19(3) 109-115

[27].Schuler, R.S., Jackson, S.E. and Tarique, I. (2011), 'Global Talent Management and Global Talent Challenges: Strategic Opportunities for IHRM', Journal of World Business, 46, 506-516.

[28]. Thiriku, M. \& Were, S. (2016). Effect of Talent Management Strategies on Employee Retention among Private Firms in Kenya: A Case of Data Centre Ltd - Kenya. International Academic Journal of Human Resource and Business Administration, 2 (2), 145-157

[29]. Thiriku, J. N. (2013). Perceived Factors Affecting Employee Retention in Safaricom Limited. Unpublished doctoral dissertation, University of Nairobi.

[30].Thunnissen, M., Boselie, P. \& Fruytier, B. (2013). Talent Management and the Relevance of Context: Towards a Pluralistic Approach, Human Resource Management Review 23: 326-336.

[31]. Wambui, N (2012). Talent Management Practices in Commercial State Corporations in Kenya. (Unpublished Master Thesis, university of Nairobi). 